University of Puget Sound

Sound Ideas

All Faculty Scholarship

Faculty Scholarship

$2-1-2013$

\title{
Origin Myths: Susano-o, Orikuchi Shinobu, And The Imagination Of Exile In Early Japan
}

Jonathan Stockdale

University of Puget Sound, jstockdale@pugetsound.edu

Follow this and additional works at: http://soundideas.pugetsound.edu/faculty_pubs

\section{Citation}

Stockdale, Jonathan. 2013. "Origin Myths: Susano-O, Orikuchi Shinobu, and the Imagination of Exile in Early Japan." History Of Religions 52(3): 236-266.

This Article is brought to you for free and open access by the Faculty Scholarship at Sound Ideas. It has been accepted for inclusion in All Faculty Scholarship by an authorized administrator of Sound Ideas. For more information, please contact soundideas@pugetsound.edu. 


\section{CHICAGO JOURNALS}

Origin Myths: Susano-o, Orikuchi Shinobu, and the Imagination of Exile in Early Japan Author(s): Jonathan Stockdale

Source: History of Religions, Vol. 52, No. 3 (February 2013), pp. 236-266

Published by: The University of Chicago Press 


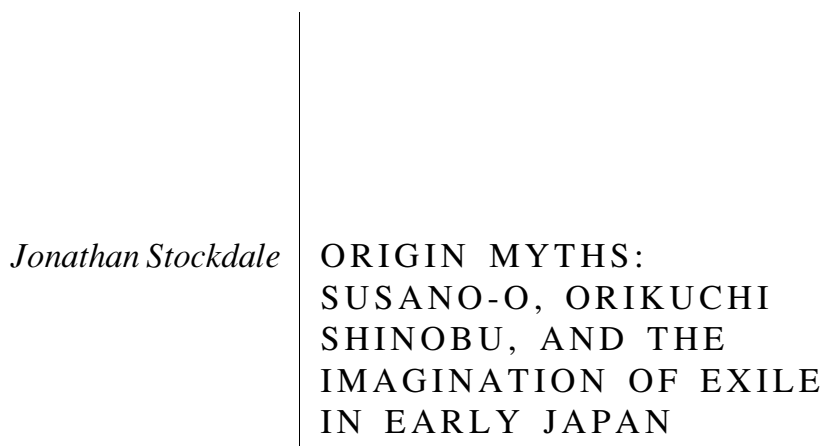

Thus saying, [Izanagi] banished [Susano-o] with a divine banishment. $(\text { KOJIKI })^{1}$

In the darkest region of the political field, the condemned man represents the symmetrical, inverted figure of the king. (Michel FouCAULt) ${ }^{2}$

The earliest example of a narrative imagining exile in Japan appears in the oldest extant chronicle of the Yamato court, the Kojiki (Record of ancient matters). In the well-known sequence from that myth-history, the Kojiki relates how the god Susano-o was banished not once, but twice: first by decree of the divine progenitor Izanagi, and then, following further transgressions on Susano-o's part, by council of the myriad deities. Following this second decree, the Kojiki recounts Susano-o's descent from the High Heavenly Plain to the ancient province of Izumo, where his character undergoes a dramatic shift. ${ }^{3}$

\footnotetext{
${ }^{1}$ Kurano Kenji and Takeda Yūkichi, eds., Kojiki/Norito, in Nihon Koten Bungaku Taikei, vol. 1 (Tokyo: Iwanami Shoten, 1966), 72-73; cf. Donald L. Philippi, trans., Kojiki (Tokyo: University of Tokyo, 1968), 73. Translations from the Japanese in this article are my own unless otherwise indicated.

${ }_{2}^{2}$ Michel Foucault, Discipline and Punish, trans. Alan Sheridan (New York: Vintage Books, 1995), 29.

${ }^{3}$ The ancient province of Izumo corresponds largely to present-day Shimane prefecture, located along the Japan Sea coast in southwestern Honshū, the main island of Japan.
} 
Rather than continuing to transgress against the constellation of power inaugurated by Izanagi, Susano-o displays his reverent support: upon discovering a sacred sword in Izumo, he offers it up to the sun goddess Amaterasu, who later includes it among the regalia she entrusts to her offspring. Those descendents, according to the Kojiki, include the very rulers who ordered the text's compilation and editing in the first place, a process that led to a finished text in $712 \mathrm{CE}$.

The "heavenly transgressions" (amatsu tsumi) leading to Susano-o's banishment-including his defecating in the sacred hall used by Amaterasu for tasting the first rice and other acts that caused her to withdraw into the heavenly rock chamber-have inspired some of the more creative exegetical efforts seen in the field of Japanese myth. Writing in the eighteenth century, the nativist scholar Motoori Norinaga (1730-1801) held that Susano-o's acts revealed his true character as an evil deity (ashiki kami), in contrast to his kind and benevolent sister Amaterasu. ${ }^{4}$ More recently, Susano-o has been cast as a representative of the warrior class, ${ }^{5}$ an archetypal trickster figure, ${ }^{6}$ a model of antistructural disorder, ${ }^{7}$ and as a cosmic giver and taker of life, ${ }^{8}$ among other possibilities. Indeed, if one of the defining features of myth lies in its openness to interpretation, ${ }^{9}$ perhaps nowhere is this malleability more on display than in the hands of its scholarly interpreters. ${ }^{10}$

More interesting for an exploration of the theme of exile is the interpretation given by the Japanese ethnologist Orikuchi Shinobu (1887-1953). Beginning in 1920, Orikuchi argued not only that the Susano-o cycle shared in the widespread fascination with exile seen in early Japanese myth, literature, and cult but also that Susano-o's transgressive grieving expressed the same poi-

\footnotetext{
${ }^{4}$ Motoori Norinaga, Kojikiden, in Motoori Norinaga Zenshū, vol. 1, ed. Motoori Toyokai (Tokyo: Yoshikawa Kōbunkan, 1926), 360. Along similar lines, see Matsumae Takeshi, "The Heavenly Rock-Grotto Myth and the Chinkon Ceremony," Asian Folklore Studies 39, no. 2 (1980): 9-22.

${ }^{5}$ See C. Scott Littleton, "Susa-no-wo versus Ya-mata no woroti: An Indo-European Theme in Japanese Mythology," History of Religions 20, no. 3 (1981): 269-80; and Allan Grapard, "Visions of Excess and Excesses of Vision: Women and Transgression in Japanese Myth," Japanese Journal of Religious Studies 18, no. 1 (1991): 3-22.

6 See Cornelius Ouwehand, "Some Notes on the God Susa-no-o," Monumenta Nipponica 14, nos. 3-4 (1958-1959): 384-407; and Robert Ellwood, "A Japanese Mythic Trickster Figure: Susa-no-o," in Mythical Trickster Figures, ed. William Hynes and William Doty (Tuscaloosa: University of Alabama Press, 1993), 141-58.

7 Alan Miller, “'Ame No Miso-Ori Me' (The Heavenly Weaving Maiden): The Cosmic Weaver in Early Shinto Myth and Ritual," History of Religions 24, no. 1 (1984): 27-48.

${ }^{8}$ Nelly Naumann, "Sakahagi: The 'Reverse Flaying' of the Heavenly Piebald Horse," Asian Folklore Studies 41, no. 1 (1982): 7-38.

9 Wendy Doniger O'Flaherty, Other Peoples' Myths: The Cave of Echoes (New York: Macmillan, 1988), 31-32.

${ }^{10}$ See particularly the epilogue "Scholarship as Myth" in Bruce Lincoln, Theorizing Myth: Narrative, Ideology, and Scholarship (Chicago: University of Chicago Press, 1999), 207-16.
} 
gnant longing felt by all Japanese for a lost spiritual homeland. Nostalgic, essentializing, and ahistorical, Orikuchi's interpretation is scarcely tenable today, yet it does have the value of drawing our attention to the widespread theme of exile seen in narratives of the early Japanese court. And while scholarship since Orikuchi's time has turned toward reconstructing the social, historical, and political conditions surrounding the production of early Japanese myth, largely missing from these efforts has been a sustained, systematic exploration of the topic of exile. As a result, the role of exile in the royal mythhistories - and in the wider court society for which those narratives were produced-remains opaque. ${ }^{11}$

In this article, I shed light on narratives of exile concerning the god Susano-o by reconsidering the myth cycle alongside other texts and ritual practices of the early Yamato court. Given the gravitational pull still exerted by his theories, I begin by retracing briefly the conception of exile in early Japan put forth by Orikuchi- the most widely known scholar to have identified and theorized the theme-while critiquing his approach as a modern form of nativist myth making. I then highlight current scholarly approaches toward the textual projects of the Yamato court that can help illuminate the role of exile in the court's earliest myth-histories. Finally, placing those texts within the wider frame of early Japanese court ritual, I examine the early state's efforts to establish a kind of public transcript-a sacred script and royal theater authenticating a particular constellation of power centered around the sovereign. In doing so, I offer a new approach to the recurring theme of exile seen in Japanese court culture, exploring exile as a trope through which members of court society revealed and reimagined their world and the circulation of power within it, both sacred and otherwise.

\section{ORIKUCHI SHINOBU AND THE KISHU RYŪRITAN GENRE}

If it is true that "any account of early Japan must deal critically with the modern agendas that form the field," 12 certainly no discussion of exile in early Japan can afford to overlook the work of Orikuchi Shinobu. And while important critiques of his interpretive method have been raised over the years, ${ }^{13}$ no

\footnotetext{
${ }^{11}$ I adapt the term myth-history from Gary Ebersole to refer to the earliest chronicles of the Japanese court (the Kojiki and the later Nihon shoki), which are neither "purely" myth nor history, but which begin by recounting the "age of the gods" before moving on to narrate (with varying degrees of accuracy) the history of the Yamato court; a primary motive of both texts was to authenticate the court through a narrative of divine origins; see Gary Ebersole, Ritual Poetry and the Politics of Death in Early Japan (Princeton, NJ: Princeton University Press, 1989), 3.

${ }^{12}$ Thomas LaMarre, Uncovering Heian Japan: An Archaeology of Sensation and Inscription (Durham, NC: Duke University Press, 2000), 5.

${ }^{13}$ The work of probing Orikuchi's intellectual context has been carried out primarily by historians. On the political-historical context of the minzokugaku (native ethnology) discipline, includ-
} 
one has yet offered a more enduring explanation for the widespread presence of exile as a trope within the narratives of the early Japanese court. ${ }^{14}$ Orikuchi's work thus occupies a curious position-still referenced today, even as scholarly currents have largely moved beyond the hermeneutics of nostalgia that led to his conclusions. ${ }^{15}$ At the outset of my article therefore, I begin by retracing briefly Orikuchi's approach toward exile narratives, leading up to his treatment of the banishment of Susano-o as paradigmatic within that genre. In doing so, I'll explain why we must move beyond Orikuchi's framework in order to place exile narratives such as the Susano-o cycle within their more appropriate historical, social, and theoretical contexts.

As part of his quest to uncover the origins of what he felt to be a uniquely Japanese cultural heritage, Orikuchi put forth a number of influential theories, among which one of the most well known is his concept of the kishu ryūritan (貴種流離譚) genre. With that phrase, he identified and gave name to an ancient genre of stories (tan) that narrated the exile or wandering (ryüri) of persons or beings of high birth (kishu) to lowly and marginal places. As he described the genre in an early work, "In the narrative poetry handed down from ancient Japan, there are tales that relate the wandering to various lands of frail and delicate people, exalted as of the offspring of divinities. I have come to refer to these together by the name 'tales of exiled and wandering nobles' [kishu ryüritan]. ... Such stories are countless; they appeared early on and continued to grow." ${ }^{\text {" }}$ Building on this concept throughout his work, Orikuchi came to believe he had discovered in the kishu ryüritan genre the

ing Orikuchi's involvement, see H. D. Harootunian, "Figuring the Folk: History, Poetics, and Representation," in Mirror of Modernity: Invented Traditions in Modern Japan, ed. Stephen Vlastos (Berkeley: University of California Press, 1998), 155; and Kevin Doak, "Building National Identity through Ethnicity: Ethnology in Wartime Japan and After," in Journal of Japanese Studies 27, no. 1 (2001): 1-39.

${ }^{14}$ Scholars in the west who have examined exile narratives from Heian Japan have largely focused on uncovering the models on which fictional characters were based. See the helpful discussions in the chapter "The Informing Image" in David Pollack's The Fracture of Meaning (Princeton, NJ: Princeton University Press, 1986); and the chapter "The Poetics of Exile" in Haruo Shirane, The Bridge of Dreams: A Poetics of the Tale of Genji (Stanford, CA: Stanford University Press, 1987).

${ }^{15}$ Western scholars of Japanese literature frequently cite Orikuchi's concept in their own discussions of works which fall under his category (such as the Taketori Monogatari or the Tale of Genji), though generally without examining Orikuchi's larger theoretical framework or contextualizing his position as an influential scholar working at Kokugakuin University during the interand postwar periods. See Norma Field, The Splendor of Longing in the Tale of Genji (Princeton, NJ: Princeton University Press, 1987), 33-34; Haruo Shirane, Bridge of Dreams, 3-4; and, more recently, Monika Dix, "Hachikazuki: Revealing Kannon's Crowning Compassion in Muromachi Fiction," Japanese Journal of Religious Studies 36, no. 2 (2009): 286-87.

${ }^{16}$ Orikuchi Shinobu, Orikuchi Shinobu zenshū, ed. Orikuchi Hakushi Kinenkai (Tokyo: Chūō Kōronsha, 1955), 7:344. While ryūri is frequently translated as "wandering," important figures within Orikuchi's genre (such as Kaguyahime) remain in a single, fixed location throughout their period on the margins. I translate the term accordingly as "exile and wandering." 
sentiment animating ancient Japan's mythic and literary traditions, recurring again and again in tales of separation and longing involving exalted figures of exile. $^{17}$

Several features of Orikuchi's theory bear noting here. First, Orikuchi introduced the kishu ryüritan concept within his early work Nihon Bungaku no Hassei (The emergence of Japanese literature). ${ }^{18}$ In that study, Orikuchi was concerned to trace the various strands he believed combined to form the Japanese literary tradition, central among which he felt was the lineage of stories concerning "exiled and wandering nobles." As he put it, "Such sacred narratives, which in the beginning came down as the tales of reciters [katar$i b e$ ] from a distant sacred place, came into contact with historical reality and then parted again, gradually growing heavy with sadness as tales of the human world. ... Threading along in this manner, one after another, a single lineage of ryüritan can be found." ${ }^{19}$ Variants on the kishu ryüritan theme continued to be generated down through the Heian period, Orikuchi believed, until the genre reached its most complete expression in the Genji Monogatari, after which changing social conditions led to the decline of new variants. ${ }^{20}$ For Orikuchi, the kishu ryüritan genre thus provided a crucial link between the earliest utterances associated with the gods and the growth of a native literary tradition, linking archaic myth and orality with the emergence of historical and literary narrative.

Second, Orikuchi held that each of the stories within the genre shared certain structural elements in common, among the most important of which was the presence of transgression. Citing both the Genji and the Taketori Monogatari as examples, he wrote: "The cause of the Shining Genji's banishment (ryūzan) to Suma was that a transgression (okasu koto) had occurred.... And though the transgression was of a different type, the Taketori's Kaguyahime too, in the end just before she ascended to heaven, told the old man that she

\footnotetext{
${ }^{17}$ Helpful discussions of Orikuchi's kishu ryūritan theory can be found in Takahashi Tōru, "Kishu ryūritan no kōzō," Kokubungaku kaishaku to kanshō 56, no. 10 (1991): 123-28; and Yamaoka Yoshikazu, "Kishu ryūritan to wa nanika," Kokubungaku: Kaishaku to kyōzai no kenkyu 54, no. 4 (2009): 6-14.

18 The portion of Nihon Bungaku no Hassei containing Orikuchi's earliest use of the term kishu ryūritan was published in 1924. Takahashi Tōru ("Kishu ryūritan no kōzō," 127-28) points out that Orikuchi's mentor in the field of Japanese ethnology, Yanagita Kunio, had earlier touched on the theme of the royal exile in his 1920 essay "Nagasare-o" (The exiled king), which can be found in Yanagita Kunio, Hitotsume kozō: Sono hoka (Tokyo: Oyama Shoten, 1934). Yanagita, in turn, had been influenced by his reading of Die Götter im Exil (Gods in exile), an 1854 work by the German poet and literary critic Heinrich Heine.

${ }_{19}$ Orikuchi, Orikuchi Shinobu zenshū 7:351.

${ }^{20}$ Ibid. 7:344, 351. Tokue Motomasa argues that the spirit of the kishu ryüritan tradition continued on within the performing arts of the medieval period; see his article "Kishu ryūritan igoOrikuchigaku no tenkai,” Kokubungaku: Kaishaku to kyōzai no kenkyū 20, no. 1 (1975): 111-16.
} 
was a heavenly being, but that because of a trivial offense (isasaka no okashi) she had committed, she had come to live in the human world." ${ }^{21}$ Incorporating this theme of transgression, Nomura Jun'ichi offers a concise restatement of the kishu ryüritan genre: "In this way, Orikuchi Shinobu named a related group of monogatari in which an originally noble hero or heroine, usually burdened with having committed a transgression, wanders in a lowly place, and he called them 'tales of exiled and wandering nobles.",22

Third, a crucial feature of the genre for Orikuchi was the emotional appeal he believed such narratives held for their audiences - an appeal rooted in their tragic nature. As he explained in a section of The Emergence of Japanese Literature titled The Tragic Spirit (higeki seishin) in Folk Literature, "even in happy tales, we discover for whatever reason the traces of pure tears flowing." ${ }^{, 23}$ As a result, through all the different manifestations of the kishu ryüritan genre, Orikuchi felt that a common tragic storyline imparted an essentially unchanging emotional impact: "There is a sense of wanting to feel sad (kanashimitai) about a familiar plot. Even when there are slight changes regarding the insertion of a character or an incident, the broader plot has not been changed. I think we don't even realize how much such things have fostered the spirit of Japanese literature." 24 For Orikuchi, this sentiment-the ability to be moved by poignant stories of separation and longing-itself provided a way of understanding the world: "to the people of old, the stories leading up to the Tale of Genji stimulated their spirits as a kind of knowledge (chishiki)."25

Orikuchi's understanding of the kishu ryüritan genre grew over time to include an ever-wider set of narratives that he viewed as variants on a more fundamental theme. From the beginning, however, his approach to the genre revolved around a few basic principles - that a single lineage linked earlier stories about gods with the heroes and heroines of the folk and classical tradition, all of whom, usually due to some transgression, found themselves in exile or wandering far from a distant center. Such stories, according to Orikuchi, helped cradle the Japanese literary tradition from infancy to maturityfrom orality to literature-and in doing so, served to move and instruct people's hearts as a native form of knowledge.

\footnotetext{
${ }^{21}$ Orikuchi, Orikuchi Shinobu zensh $\bar{u}$ 7:244.

22 Ariyama Daigo and Ishiuchi Tōru, eds., Chōkū/Orikuchi Shinobu Jiten (Tokyo: Bensei Shuppan, 2000), s.v. "kishu ryüritan," by Nomura Jun'ichi. See also the discussion of transgression within the kishu ryüritan genre in Yamaoka Yoshikazu, "Kishu ryūritan to wa nanika," 6-7.

${ }^{23}$ Orikuchi, Orikuchi Shinobu zensh $\bar{u}$ 7:351. For a discussion of Orikuchi's attraction to narratives of suffering and sorrow, see Takahashi Tōru, "Kishu ryūritan no kōzō," 123, 128.

${ }^{24}$ Orikuchi, Orikuchi Shinobu zensh $\bar{u}$ 7:352.

${ }^{25}$ Ibid. 7:344.
} 
ORIKUCHI AND THE SUSANO-O MYTH

While these features of Orikuchi's genre are generally known to scholars who invoke the kishu ryüritan concept, further elements of his theory become visible only upon examining his treatment of particular exile narratives. We can see this by looking more closely at the myth involving Susano-o, while observing Orikuchi's method of interpretation. In order to see how Orikuchi employs a kind of wordplay focusing on select details, I begin by quoting the original passage from the Kojiki regarding Susano's initial banishment. The section opens just after the divine progenitor Izanagi has returned from visiting his dead mate Izanami in the underworld; in the process of purifying himself from the defilement of such a journey, he has generated numerous offspring.

At this time Izanagi-no-mikoto, rejoicing greatly, said, "I have borne child after child, and finally in the last bearing I have obtained three noble children."

Then he removed his necklace, shaking the beads on the string so that they jingled, and, giving it to Amaterasu-o-mi-kami, he entrusted her with her mission, saying, "You shall rule Takama no hara."

The name of this necklace is Mi-kura-tana-no-kami.

Next he said to Tsuku-yomi-no-mikoto, entrusting him with his mission, "You shall rule the realms of the night."

Next he said to Take-haya-Susano-o-no-mikoto, entrusting him with his mission, "You shall rule the ocean."

While [the other deities] ruled [their realms] in obedience to the commands entrusted to them, Haya-Susa-no-o-no-mikoto did not rule the land entrusted to him. [Instead], he wept and howled [even] until his beard eight hands long extended down over his chest.

His weeping was such that it caused the verdant mountains to wither and all the rivers and seas to dry up. At this, the cries of malevolent deities were everywhere abundant like summer flies and all sorts of calamities arose in all things.

Then Izanagi-no-o-mi-kami said to Haya-Susano-o-no-mikoto, "Why is it you do not rule the land entrusted to you, but [instead] weep and howl?"

Then [Haya-Susano-o-no-mikoto] replied, "I wish to go the land of my mother [haha no kuni], Ne-no-katasu-kuni. That is why I weep."

Then Izanagi-no-o-mi-kami, greatly enraged, said, "In that case, you may not live in this land!"

Thus [saying], he banished him with a divine banishment [kamuyarahi ni yarahitamahiki]. ${ }^{26}$

\footnotetext{
${ }^{26}$ Philippi, Norito, 71-73, modified; see Kurano and Takeda, Kojiki/Norito, 73. Note that in the Kojiki text Susano-o himself identifies his “mother's land” as Ne-no-katasu-kuni (根之堅州国), the "Land of Firm Roots," a subterranean region usually associated by scholars of Japanese myth with Yomi no kuni (黄泉国), the realm of the dead where Izanagi encountered Izanami’s corpse.
} 
Even in this brief passage we can see how Susano-o's banishment illustrated for Orikuchi the impulse which lay behind the kishu ryūritan genre, centering around a hero of divine birth who is forced to wander far from a sacred center due to his transgressive behavior. In his commentary on the story, however, Orikuchi goes on to discuss the meaning of the myth for the Japanese people and the reason for its enduring impact over time. Focusing on the prolonged mourning Susano-o displayed for his "mother" Izanami and his stated desire to go to the land where she resides, Orikuchi writes: "The mother-land [haha ga kuni] that Susano-o cried longingly for, turning green mountains barren, and from which Inahi no mikoto [in the Kojiki] came riding along the wave tops, is the spiritual homeland that our ancestors [ware ware no oyatachi] longed for. Generations of storytellers have explained that it is called their 'mother's land' because [Susano-o's mother] Izanami and [Inahi no mikoto's mother] Tamayori-hime retired there, but the truth is that these stories narrate the longing felt by everyone [bannin] for the original land [mototsu kuni]."27 For Orikuchi, the fact that Susano-o wished to go to "the land of my mother"- - haha ga kuni-actually revealed the yearning among all Japanese for an original, lost "motherland" (a phrase expressed identically in Japanese: haha ga kuni). In Orikuchi's creative exegesis, "land of my mother" thus becomes "motherland," which then transforms effortlessly into "the original land" (mototsu kuni).

Orikuchi's reference to an "original land" in the passage above refers to a final feature of his theoretical framework, the concept of tokoyo (literally, "eternal world"). While references to a land of the gods known as tokoyo appear in the earliest Japanese texts, Orikuchi had his own unique understanding of the term. In his view, tokoyo referred to the distantly remembered ancestral homeland - misremembered as the eternal realm of the gods-from which he believed the Japanese people existed as if in a state of exile. To Orikuchi, the beliefs found in Japan regarding an otherworldly tokoyo sprang from prehistoric origins, representing the dimly remembered details told to countless generations of children by their elders about a land from which they had long ago migrated. Sometime after reaching the Japanese archipelago, Orikuchi believed, the link between these stories and an actual place was forgotten, and what remained was simply a blurred memory of the "otherworld," which endured as a crucial trope in the cultural imagination, inspiring a powerful longing for a forgotten spiritual home. Orikuchi described this process in a passage from 1920:

About the distant past, when our ancestors came to live in this country, those events are handed down in the tales told by reciters [kataribe]. Regarding the original land

${ }^{27}$ Orikuchi, Orikuchi Shinobu zenshū 2:6. 
[mototsu kuni], archeologists, comparative linguists and ancient historians provide no more than some supporting evidence. Their children and grandchildren may have known faintly about a previous land their parents had never visited, but even this was soon forgotten, and all that remained was a feeling of yearning for the original land, instilled in them by their forefathers. I believe that this force, which inspired our ancestors one or two thousand years ago, lives on in our hearts even today. ${ }^{28}$

As seen in his final sentence, Orikuchi felt that the longing for a spiritual homeland connected the ancient Japanese with his contemporaries in the present; he even described how he, too, had once experienced the force of this longing for the "distant sacred place": "Ten years ago I traveled to Kumano, and as I stood on the very tip of cape Daiō, sticking out into the ocean and glittering in the midday sun, I couldn't help feeling that our spiritual home [waga tamashii no furusato] lay at the end of a distant sea voyage. Even today, I can't pass this off as just the affected sentiment of a hopeless poet. ${ }^{29}$ Is it not an atavism, an appearance of the nostalgia that once stirred the hearts of our ancestors?"30 Orikuchi's remarks thus speak of more than simply his belief in tokoyo, for in that moment at the shore Orikuchi felt he had encountered the spiritual inheritance of all Japanese people: a poignant feeling of longing born of separation from a sacred homeland.

With Orikuchi's views regarding tokoyo in mind, we are now prepared to examine the full context of his kishu ryüritan theory. In Orikuchi's broadest understanding, the Japanese literary tradition originated as divine utterances handed down from a "distant sacred place," transmitted initially by oral reciters, which later developed into more complex and varied narratives giving voice to the longing for a lost home, the original "motherland." For Orikuchi, the kishu ryüritan genre represented the highest expression of this originary theme of longing, inspiring story upon story that narrated the poignant sorrow of gods, heroes, and heroines who found themselves far from a sacred center. ${ }^{31}$ Ultimately, Orikuchi believed, narratives of estrangement such as Susano-o's captured the hearts of the early Japanese exactly because they

${ }^{28}$ Ibid. 2:4-5; see also Kamata Tōji, "The Disfiguring of Nativism: Hirata Atsutane and Orikuchi Shinobu," in Shinto in History, ed. John Breen and Mark Teeuwen (Honolulu: University of Hawai'i Press, 2000), 310.

${ }^{29}$ Orikuchi was a noted poet whose work garnered literary prizes under the pen name Shaku Chōkū; in the postwar period he was a participant in the annual imperial poetry gatherings. Like earlier Kokugaku scholars, he too felt that classical poetic forms provided a means for developing an empathetic relation to authors of the ancient literary tradition.

${ }^{30}$ Orikuchi, Orikuchi Shinobu zenshū 2:5, emphasis in original; see also Kamata, "Disfiguring of Nativism," 310.

${ }^{31}$ For Orikuchi, the journey from center to periphery continued to trace itself over and over again in the Japanese imagination, producing recurring stories of estranged heroes who were at the same time rare or divine visitors. Thus, in addition to his ideas regarding tokoyo, a further concept helpful for understanding the kishu ryüritan theme is his theory of marebito, or divine visitors. In 
replayed an archetypal experience that stood at the beginning of Japanese historical consciousness and that remained dimly present within the hearts of the Japanese all the way down to the modern period.

\section{THE HERMENEUTICS OF NOSTALGIA}

What are we to make of Orikuchi's imaginative interpretation of Susano-o and of his broader conception of exile narratives? We can begin by acknowledging that Orikuchi at once recognized and misrecognized the exile genre in early Japan. On the one hand, his linking of early myths such as Susano-o with much later literary works such as the Genji indeed points to the recurring trope of exile in the narratives of the Japanese court-although in retrospect this does not go much farther than attesting to historical fact. Orikuchi went much further in his attempt to explain the appeal of such narratives, on the other hand, and this is where his theories quickly become problematic. Without going into an exhaustive discussion of his work, we can simply point to two main weaknesses in Orikuchi's method in order to indicate why we must move beyond the kishu ryüritan framework once and for all. ${ }^{32}$

First, Orikuchi's writings betray an ongoing quest to uncover the origins of a purely Japanese identity, untainted by "foreign" influence. In the kishu ryüritan genre, he believed he had found a uniquely Japanese narrative tradition that predated the absorption of Chinese culture. ${ }^{33}$ While Orikuchi acknowledged that "in China there were also numerous people of letters who were exiled," he didn't find in their poetry the same spirit that he perceived in Japanese waka. ${ }^{34}$ Even Japanese poets who wrote in Chinese were constrained in their powers of expression, he felt. Echoing a sentiment expressed many years earlier by the nativist scholar Motoori Norinaga, Orikuchi wrote

\footnotetext{
Orikuchi's view, when a hero 'as of an offspring of divinity' was exiled and forced to wander in a peripheral or lowly place, while he or she may be regarded as a pariah to those who occupy the center from which they were expelled, those who encounter the person on the periphery receive them as a rare or sacred visitor: a marebito. In this regard, Nomura Jun'ichi writes, the kishu ryüritan theme and the marebito category should be understood as two aspects of a similar principle, with the marebito functioning as a kind of reverse image of the kishu ryüritan theme (the hero's journey to the periphery as seen from two different perspectives); see Nomura Jun'ichi, "kishu ryūritan," in Ariyama Daigo and Ishiuchi Tōru, Chōkü/Orikuchi Shinobu Jiten; as well as Takahashi Tōru, "Kishu ryūritan no kōzō," 124-25.

${ }^{32}$ For further critical reflections on Orikuchi's work, see Kamata, "Disfiguring of Nativism," 295-317; and Osamu Murai, Han Orikuchi Shinobu ron (Tokyo: Sakuhinsha, 2004), 24-46.

${ }^{33}$ As Thomas LaMarre (Uncovering Heian Japan, 2-3) describes this move, "scholars must posit the existence of an already-unified Japan before the advent of Chinese practices; the scholarly emphasis therefore falls on whatever seems to come before, or lie outside, continental customs, scripts, institutions, and so on. This involves a tendentious search for anything that does not seem marked as 'foreign'; these (by default) 'native' elements are then drawn into the imagination of a Japan before and beyond China."

${ }^{34}$ Orikuchi, Orikuchi Shinobu zensh $\bar{u}$ 7:348.
} 
of such poets: "what a dreadful thing, being confined within the expressions of Chinese verse." 35

Orikuchi's approach thus reveals the continuing imprint of the Kokugaku (national learning) movement of the eighteenth and nineteenth centuries, whose leading scholars combined philological rigor and protonationalist zeal to project onto the earliest Japanese texts the image of an idealized community: pure, untainted, and thereby sacred. ${ }^{36}$ Such nativist faith in the existence of a pure Japanese spirit-as simple to critique as it is difficult to dispelplainly overlooks the complex interweaving of (what we now see as) Chinese, Japanese, and Korean elements in the cultural life of the Yamato court which extends as far back as textual traces can be found. ${ }^{37}$ While Orikuchi sought to disentangle strands of a native tradition from the continental influences that enabled writing to occur in the first place, such claims evaporate the moment we consider, for example, that the Tang Chinese poet (and exile) Bai Juyi (白居易, 772-846) was among the most acclaimed of the Heian period or that his Chinese poem The Song of Everlasting Sorrow frames the opening of the Tale of Genji, so cherished by Orikuchi as the apex of the kishu ryüritan genre. ${ }^{38}$ Such reminders help to underscore the affinities, rather than the differences, that existed between the Yamato and Chinese courts, even-or especially - with regard to exile. More broadly, amid the complex mixture of migration from the Korean peninsula, cultural exchange with the Chinese courts, and the archipelago's own ethnic and linguistic hybridity, the idea of a purely Japanese spirit in antiquity remains fundamentally a nativist fantasy. ${ }^{39}$

\footnotetext{
${ }^{35}$ His full sentence reads “恐ろしいもので, 漢詩の表現に囚はれて、日本式なものが 出て居ない”; Orikuchi, Orikuchi Shinobu zenshu 7:347. Compare Motoori Norinaga's comment from Naobi no mitama: "[People are] going astray, fenced in within the confines of the Chinese classics” (漢籍の垣根のなかをさ迷っている); Motoori Norinaga, ed. Ishikawa Jun, vol. 21 of Nihon no meicho (Tokyo: Chūō Kōronsha, 1970), 179.

${ }^{36}$ For discussions of the Kokugaku project focusing on various early modern Japanese scholars, see Peter Nosco, Remembering Paradise: Nativism and Nostalgia in Eighteenth-Century Japan (Cambridge, MA: Council on East Asian Studies, 1990); H. D. Harootunian, Things Seen and Unseen: Discourse and Ideology in Tokugawa Nativism (Chicago: University of Chicago Press, 1988); Mark McNally, Proving the Way: Conflict and Practice in the History of Japanese Nativism (Cambridge, MA: Harvard University Asia Center, 2005); and Wilburn Hansen, When Tengu Talk: Hirata Atsutane's Ethnography of the Other World (Honolulu: University of Hawai' 'i Press, 2008).

${ }^{37}$ See LaMarre, Uncovering Heian Japan, 5.

${ }^{38}$ See Burton Watson, trans., Po Chu-I: Selected Poems (New York: Columbia University Press, 2000), vii-xvi. Bai (or Bo) Juyi is the poet's name in the pinyin system of romanization; in Japan he is known more widely as Haku Rakuten (白楽天).

${ }^{39}$ While I draw attention here to influences on Orikuchi from the older Kokugaku movement, Orikuchi believed himself to be at the vanguard of a "new Kokugaku" (Shin Kokugaku), a movement that would combine the classical training of the older nativist scholars with the emerging discipline of native ethnology (minzokugaku) in order to trace links between archaic Japan and the contemporary Japanese "folk"; see Orikuchi, Orikuchi Shinobu zenshū 3:496-97; as well as Harootunian, "Figuring the Folk," 144-45.
} 
In addition to imagining a purely "Japanese" past, a second problem with Orikuchi's approach lies in his appeal to a Japanese spirit that transcends history. As we've seen, Orikuchi located the enduring quality of the kishu ryüritan genre in the emotional appeal it held for all Japanese- - throughout time-due to the longing it stirred for a lost spiritual homeland. His approach thus operates by imposing a modern image of community onto early Japan, seeking to construe ancient narratives as the foundations of a single, enduring national identity. Yet as scholars have increasingly pointed out, the original textual community of the court chronicles was entirely different. Locating the texts in the social conditions of their late seventh- and early eighth-century genesis, Isomae Jun'ichi writes,

The constituency of the myths in ancient times was limited to clan members who were integrated according to their political functions into the Yamato court centered on the imperial house. The people [and gods] who appeared in the myths were the ancestors of the clans that constituted the court.... Thus, the people who lived in the land of Japan did not look to the myths of the Kojiki and Nihonshoki for some portrayal of the origins of "the people" (aohitogusa) because ... in antiquity the common people appeared only as objects of the rule of the Yamato court. ... Because of their political functions, the myths were possessed exclusively by the court. ${ }^{40}$

For modern scholars to claim the myths as a treasury revealing the spiritual heritage of all Japanese people thus requires a prior transformation in social relations, textual production, and interpretive practice-not to mention an early modern image of national community. As Isomae points out, this was conceivable only after the political power of the court legitimated by the texts had faded during the medieval period, publishing technologies had made the texts widely available (in conjunction with the rise of book lenders), and a nativist movement had reinterpreted the texts as the classical site of an enduring national spirit. When all of these elements came together, he writes, "The myths of the Kojiki and Nihonshoki were freed from their political constraints in the early modern period to become relevant to a wide range of social classes. The constituency of the myths expanded to include all people who lived in the realm ... [and] because by now the myths did not contain any direct referent [to an existing court society], anyone could take part in them simply by living in Japan." ${ }^{41}$ Orikuchi's reading of the Susano-o myth as a poignant expression of the longing felt by all Japanese people, throughout time, is thus

\footnotetext{
${ }^{40}$ Isomae Jun'ichi, Japanese Mythology: Hermeneutics on Scripture (Oakville, CT: Equinox, 2010), 27.

${ }^{41}$ Ibid., 28-29; as Isomae mentions, "this close linkage of the Kojiki and Nihonshoki myths to the non-ruling strata does not appear before the advent of Nativism: it was an epochal development" (25).
} 
an interpretation based on a radical dehistoricizing of the royal myth-histories, a move which fundamentally misrepresents the historical context of the early Japanese court.

More than illuminating the ancient past, Orikuchi's theories shed light most clearly on the historical setting of his own writing. As an influential scholar at Kokugakuin University during the turbulent interwar years, Orikuchi's mythic account of the origins of the Japanese spirit sought to erase any divide between the archaic and modern periods, offering the possibility of a spiritual engagement with the past for the disenchanted modern audiences he was concerned to address. Yet if such expressions of "desire for an origin that could never be reached" remained a hallmark of Japanese scholarship laboring in the wake of the National Learning movement, this also means that scholars today who invoke Orikuchi's kishu ryūritan genre do so at the risk of reproducing a distorted image of the Japanese past. ${ }^{42}$ Nostalgic, essentializing, and ahistorical, the kishu ryüritan theory is genuinely problematic-and a fresh approach to exile narratives in early Japan is long overdue.

\section{REREADING THE JAPANESE MYTH-HISTORIES}

If Orikuchi's interpretation of early Japanese myth in many ways constitutes its own modern mythology, how might we better locate the significance of the royal myths for the court society in which they originally circulated? More specifically, what relations might we trace between myths imagining the exile of a god, on the one hand, and the social world in which such narratives were produced, on the other? And what might this tell us, in turn, about the widespread presence of exile as a trope within early Japanese narrative?

To begin addressing such questions, we can start by examining the nature of "myth" in the myth-histories themselves. In contrast to nativist-influenced views such as Orikuchi's, the work of several generations of scholars clearly shows that the court-sponsored myth-histories were not simply unreflective compilations of early Japanese oral tradition but resulted instead from concerted efforts by members of the Yamato court to trace a narrative supporting the claims of the royal house to sovereignty. ${ }^{43}$ The preface to the Kojiki itself makes this clear, stating that the text resulted from the ruler Tenmu's charge to compile a coherent narrative-_- "discarding the mistaken and establishing the true"- and we can understand this at one level to indicate a narrative sup-

\footnotetext{
${ }^{42}$ Harootunian, "Figuring the Folk," 155.

${ }^{43}$ On this process, see, among others, Joan Piggott, The Emergence of Japanese Kingship (Stanford, CA: Stanford University Press, 1997); Ebersole, Ritual Poetry; Herman Ooms, Imperial Politics and Symbolics in Ancient Japan: The Tenmu Dynasty, 650-800 (Honolulu: University of Hawai' i Press, 2009); and Michael Como, Weaving and Binding: Immigrant Gods and Female Immortals in Ancient Japan (Honolulu: University of Hawai ‘i Press, 2010).
} 
porting the claims of Tenmu's line to sovereignty. ${ }^{44}$ As Kōnoshi Takamitsu has stated more generally regarding the two earliest myth-histories, "the Kojiki [712] and the Nihon shoki [720] were originally composed as a result of the need of the early ritsuryo state to authenticate itself," adding that the texts produced by that state offered "an affirmation of its own world order."45 That such an authenticating project was fundamentally genealogical is also clear from the outset of the Kojiki and Nihon shoki narratives, both of which begin by tracing the genealogies of numerous deities and continue by connecting that divine hierarchy to the social order of the Yamato court through accounts describing the descent from the heavens of the ancestral deities of various court families.

Clarifying the historiographic intent behind the state's textual projects also helps shed light on what has been a stumbling block for many interpreters of Japanese myth - the complex diversity of the mythic record from early Japan. As Kōnoshi points out regarding scholars like Orikuchi, "modern scholarship has regarded the Kojiki and the Nihon shoki, along with early ritual texts such as norito (ritual prayers), as manifestations of a single preexisting mythology" and, indeed, "as the cultural foundation of both the folk and the nation." 46 As a result, many scholars have downplayed differences between the two mythhistories as variations or divergences from a presumed "original" narrative. ${ }^{47}$ Yet there are good reasons to take such differences seriously: as Isomae Jun'ichi reminds us, "there was never a time when the Kojiki and Nihon shoki myths constituted a single, unified text: a multitude of variants, as well as the interpretations connected with each of them, coexisted side by side." ${ }^{, 48}$ In this light, rather than a single, unified mythology, the presence of variants within the very earliest texts reveals the existence of diverse sources out of which the myth-histories were composed, each in distinctly motivated ways. ${ }^{49}$

\footnotetext{
44 "Whereupon the Emperor said, "This is the framework of the state, the great foundation of the imperial influence. Therefore ... discarding the mistaken and establishing the true, I desire to hand them on to later generations"; Philippi, Norito, 41; see also Kurano and Takeda, Kojiki/Norito, $45-47$.

${ }^{45}$ Kōnoshi Takamitsu, "Constructing Imperial Mythology: Kojiki and Nihon shoki," trans. Iori Joko, in Inventing the Classics: Modernity, National Identity, and Japanese Literature, ed. Haruo Shirane and Tomi Suzuki (Stanford, CA: Stanford University Press, 2001), 52. The term ritsuryō here refers to the ritsu (penal) and ryo (administrative) law codes, which established the legal charter for the Yamato state. The Taiho ritsuryō, the earliest complete law code of the Yamato state, was promulgated in 702, a decade before the completion of the Kojiki.

${ }^{46}$ Kōnoshi, "Constructing Imperial Mythology," 52.

47 Isomae, Japanese Mythology, 30.

${ }^{48}$ Ibid, 25.

49 Kōnoshi ("Constructing Imperial Mythology," 56-59) indicates that this mythology only became homogenized in retrospect, after the compilation of the Kojiki and Nihon shoki narratives, through the retroactive labor of exegetical commentary.
} 
It shouldn't surprise, then, that the Kojiki and Nihon shoki-compiled at different moments, in different linguistic modes, and with different sources and audiences in mind-contradict each other on rather fundamental points. No "High Heavenly Plain" (Takamagahara) appears in the Nihon shoki, but only "heaven," reflecting a worldview rooted in the yin/yang dimorphism between heaven and earth. ${ }^{50}$ Nor does Izanagi's mate Izanami die in the Nihon shoki, a result of the same dimorphic principle expressed again through gendered pairs. ${ }^{51}$ Yet the situation is even more complex: not only do the two texts contradict each other, they also contradict themselves, internally. As one example, Orikuchi's exegesis of the Susano-o myth centers around the deity's mourning for his deceased mother, and this mourning is indeed recorded in the Kojiki account, yet in the same Kojiki, Izanami never gave birth to Susano-o: such a genealogy appears only in the Nihon shoki. At moments such as these there is almost a sense in which meaning hovers in the "mosaic of citations" created between the two texts, ${ }^{52}$ as long as we understand this to reflect not so much a single preexisting mythology but rather the distinctive use in each text of a diverse archive of mythic variants. ${ }^{53}$

This diverse archive - resulting from differing versions of the royal chronicles (teiki) and ancient myths (kuji) held by different clans, as well as regional variants recorded in the provincial $F u d o k i$-is reflected particularly clearly in the Nihon shoki, which presents both the official court narrative as well as variants (issho) to the main text, resulting in as many as eleven variants for a given passage. ${ }^{54}$ At times the juxtapositions within the Nihon shoki can be jarring, as when the official narrative establishing Amaterasu as blood ancestor of the royal line is accompanied by three variants in which Susano-o instead is accorded paternity. ${ }^{55}$ Given such diversity within the mythic sources, the privileging of one version as correct—-the Kojiki, for example—or the posit-

${ }^{50}$ Ooms, Imperial Politics and Symbolics in Ancient Japan, 32.

${ }^{51}$ Ibid.

${ }^{52}$ From Julia Kristeva's Semiotike: "Every text takes shape as a mosaic of citations, every text is the absorption and transformation of other texts" (in Structuralist Poetics, trans. Jonathan Culler [Ithaca, NY: Cornell University Press, 1979], 139). See also Julia Kristeva, Desire in Language: A Semiotic Approach to Literature and Art, ed. Leon Roudiez (New York: Columbia University Press, 1980), 66.

${ }_{53}$ One explanation for the numerous variants found within the Nihon shoki may be related to the court's project to collect $F u d o k i$, an effort begun during the interval between the compilation of the two myth-histories. See Michiko Aoki, Records of Wind and Earth: A Translation of "Fudoki" with Introduction and Commentaries (Ann Arbor, MI: Association of Asian Studies, 1997), 2 .

54 Isomae, Japanese Mythology, 51.

55 Ibid., 42-49. Three variants within the Nihon shoki name Susano-o (rather than Amaterasu) as the parent of Ame no Oshihomimi, who in turn fathered the "heavenly offspring" Ninigi; see W. G. Aston, trans., Nihongi: Chronicles of Japan from the Earliest Times to A.D. 697 (Tokyo: Tuttle, 1972), 33-40. 
ing of a single, preexisting mythology, simply doesn't match the available data. As a result, as Isomae Jun'ichi has suggested, rather than attempting to locate the true meaning or correct version of early Japanese myth, we might shift our attention more profitably to those moments in the historical transcript where one group has attempted to "fix" a particular reading of myth"discarding the mistaken and establishing the true," in the words of the Kojiki preface-realizing all the while that such moments come about precisely in light of, and in response to, the existence of other variant readings. ${ }^{56}$

\section{SUSANO-O MYTHOLOGY IN HISTORICAL PERSPECTIVE}

Regarding the production of the earliest myth-histories, Joan Piggott has termed the court's project one of "integrative mythology," referring to the manner in which the earliest chronicles incorporate myths and deities from other regions within narratives supporting the claims of the Yamato sovereign. ${ }^{57}$ In doing so, the mythic record reflects the court's expanding presence beyond the Yamato plain-an expansion Piggott characterizes as occurring not primarily through force, but through the assimilation of regional elites into a Yamato-centered "hierarchy of status." ${ }^{, 58}$ In this fashion, she suggests, regional leaders outside the Yamato sphere gradually became self-interested participants in the Yamato polity, receiving titles, privileges, and articles of prestige in return for their submission, loyalty, and tribute to the Yamato center. ${ }^{59}$ Likewise, as regional elites were gradually assimilated, so too their clan deities, mythologies, and cultic centers made their way into the Yamato framework as well. ${ }^{60}$

Within the Yamato myth-histories, nowhere is the process of integrative mythology more clearly evident than in the inclusion of the so-called Izumo cycle. Beginning with the exile of Susano-o to Izumo and ending with the famous land-yielding sequence-in which Susano-o's "descendent" Ōkuninushi cedes rule over the land to deities representing Amaterasu-roughly one-third of the Age of the Gods portions of the Kojiki and Nihon shoki are devoted to myth sequences taking place in Izumo and incorporating the chief deity and cultic center of that region. The presence of significant narrative strands involving Izumo within Yamato court texts thus underlies the conclu-

\footnotetext{
56 Isomae, Japanese Mythology, 47-49.

57 Joan Piggott, "Sacral Kingship and Confederacy in Early Izumo," Monumenta Nipponica 44, no. 1 (1989): 54.

58 Ibid., 60.

59 Ibid., 60; see also Piggott's Emergence of Japanese Kingship, 1-14, 150-51.

${ }^{60}$ As Como demonstrates (Weaving and Binding, xiv, 162), the process of integrating deities and cults between center and periphery was not merely a "top down" process initiated by the state, but also flowed upward, as immigrant lineages from the Asian mainland brought with them newly popular deities, cults, and innovative technologies that spread widely through grassroots channels.
} 
sion that in the court chronicles, "a new divine genealogy under Amaterasu's sovereignty incorporated deities from both areas.",61

Regarding Susano-o, however, an examination of the Izumo Fudoki-the compendium of regional data from Izumo ordered by the Yamato court in 713 and presented by Izumo to the throne in 733 — suggests once again that the integrative process was something more dynamic than a simple compilation of existing sources. On the one hand, the Izumo Fudoki clearly attests to Susano-o's status as a local divinity-mentioning his name ten times, detailing his divine offspring, and narrating the origin of his place of enshrinement at the Susa no yashiro. By comparison, his name appears in no other extant Fudoki. ${ }^{62}$ On the other hand, his status as a local deity in the Izumo Fudoki remains notably modest: absent from the text is any mention of the more grandiloquent qualities attributed to Susano-o in the court chronicles-including not only his kinship with Amaterasu and his exile from the heavenly plain but also his slaying of the eight-headed serpent in Izumo and his discovery of the Ama no murakumo sword within its body. ${ }^{63}$

By far the greater deity within the Izumo Fudoki is Ōnamuchi-known in the Yamato chronicles by the name Ōkuninushi-who is enshrined in the "great palace" of Kitsuki, known later as Izumo Taisha and situated along a major trade route on the Japan Sea coast. ${ }^{64}$ By contrast, the relative status of Susano-o's shrine is indicated by its modest setting in the village of Susa and by the mere two rice fields mentioned in the Fudoki providing for its economic support. ${ }^{65}$ Such disparities between the depiction of Susano-o in the Izumo Fudoki and in the Yamato court chronicles thus suggest a process not merely of retelling but of reimagining Izumo content within the royal mythhistories. Rather than an "Izumo cycle" contained within the Kojiki and Nihon shoki, there exists what more properly should be considered a Yamato-centered narrative employing Izumo deities. ${ }^{66}$

Given the richly detailed role played by Susano-o within the royal myths, we might expect a correspondingly rich cultic landscape surrounding the deity somewhere: if not in Izumo, then perhaps in the Yamato region. To examine

${ }^{61}$ Piggott, "Sacral Kingship," 62.

${ }^{62}$ Aoki, Records of Wind and Earth, 141 n. 165. This is suggestive, though not conclusive, of his status as a deity centered in Izumo, since no other Fudoki is extant in its entirety.

${ }^{63}$ The sword is more widely known as the Kusanagi 草薙 sword, the name retroactively given the weapon after Yamato Takeru used it on missions described later in the Kojiki and Nihon shoki. A variant in the Nihon shoki records the sword's original name as the Ama no murakumo, or "heavenly cloud gathering" sword; see Aston, Nihongi, 53.

${ }^{64}$ Miyazawa Akihisa, "Izumo no Saishi Iseki," in Izumo no Kamigami: Shinwa to Shizoku, ed. Ueda Masaaki (Tokyo: Chikuma Shobō, 1987), 47.

${ }^{65}$ Akimoto Kichiro, ed., Fudoki, in Nihon Koten Bungaku Taikei, vol. 2 (Tokyo: Iwanami Shoten, 1970), 217; see also Aoki, Records of Wind and Earth, 140-41.

${ }^{66}$ Inoue Mitsusada, Nihon no rekishi: Shinwa kara rekishi e (Tokyo: Chūō Kōronsha, 1965), 62. 
this, we can turn to the Engishiki-the mid-Heian record of the ritual and administrative protocols of the ritsury $\bar{o}$ state-which includes a valuable listing of shrines (the jinmy $\bar{o} c h \bar{o}$ ) that were recognized under the ritsury $\bar{o}$ system and that were thus entitled to receive patronage in the form of offerings from the state. ${ }^{67}$ Yet of the four shrines appearing on the list whose names suggest the worship of Susano-o, two were located in Izumo, one was in the ancient province of Bingo, and one was in Kii province-none are found within the kinai, the home provinces surrounding and including the capital. ${ }^{68}$ Here again, the contrast between the strong supporting role played by Susano-o in Yamato myth and the lack of a cultic presence attested him in the capital region is striking. ${ }^{69}$

It remains unclear how such a rich structural figure in Yamato myth could emerge from such modest origins in the Izumo region or, conversely, how a deity seemingly lacking a cultic base in the Yamato region could rise to such an important role in the royal pantheon, ${ }^{70}$ although the period during which the court chronicles were being composed was certainly a time of "Great Change" in the cultic as well as social and political spheres. ${ }^{71}$ As Matsumae Takeshi frames the situation regarding Susano-o, "There is probably no deity in Japanese mythology whose complexity matches that of Susano-o, nor therefore any who have been the focus of so much scholarly discussion.... One could even say that the question of Susano-o is the starting point for research into Japanese myth, the clarification of which might provide an important key to untangling the riddles of Japanese mythology."72 At the

\footnotetext{
${ }^{67}$ It should be noted that the ritsuryo system of shrine offerings was breaking down even while the Engishiki was being compiled, as the state gradually lost its ability to patronize such an extensive system of shrines, and as newly consecrated sited competed for state support. By the end of the Heian period, the extensive list recorded in the Engishiki had been replaced by a much more truncated system of twenty-two shrines. See Allan Grapard, "Institution, Ritual, and Ideology: The Twenty-Two Shrine-Temple Multiplexes of Heian Japan," History of Religions 27, no. 3 (1988): 246-69.

${ }^{68}$ Matsumoto Hisashi, "Susano-o shinkō no rekishi," in Ōbayashi Taryō, Susano-o shinkō jiten (Tokyo: Ebisu Kōshō, 2004), 51. Bingo, adjacent to Izumo, would be equivalent to Hiroshima prefecture today; Kii province would now be equivalent to Wakayama prefecture.

${ }^{69}$ Once again this is suggestive, though not conclusive, evidence for the worship of Susano-o across the archipelago, because not all existing shrines were listed in the jinmyōchō. According to the Izumo Fudoki, for example, out of a total of 399 shrines in Izumo, only 184 were listed as "officially recognized shrines" (kansha 官社) by the centralized Jingikan 神祇官 (department of divinities); see Ueda Masaaki, "Kamigami no genzō," in Masaaki, Izumo no Kamigami (Tokyo: Chikuma Shobō, 1987), 3-4.

${ }^{70}$ See Matsumae Takeshi, "Izumo no Shinwa," in Masaaki, Izumo no Kamigami, 90; and Mizuno Yū, Kodai no Izumo to Yamato (Tokyo: Daiwashobō, 1994), 17.

${ }^{71}$ The tumult surrounding this period is illustrated clearly in the era name chosen by the female ruler Kōtoku in 645: Taika 大化 (great change). See also the discussion by Como (Weaving and Binding, 2), who characterizes the period as one of "tremendous ferment in both the nature of the royal cult and in the cast of deities that formed its core."

${ }^{72}$ Matsumae Takeshi, Nihon no kamigami (Tokyo: Chūō Kōronsha, 1974), 47.
} 
same time, the question of the exact relation between Izumo myth and the Yamato myth-histories has been called "the hardest problem of all to solve,"73 and as Kōnoshi Takamitsu has cautioned, as long as we lack a direct window into the process of textual formation, there are reasons to be cautious about peering back any further toward sources for the earliest extant texts: as we saw with Orikuchi Shinobu, all too often such attempts have resulted in the creation of new, modern "mythologies.",74

\section{SUSANO-O AND THE IMAGINATION OF EXILE}

Questions of mythic origins notwithstanding, one thing about the relation between Izumo and Yamato mythology stands out from the court chronicles themselves - the crucial role played by exile in mapping out a Yamato-based constellation of power. At the most basic level, we see this in how the trope of exile-Susano-o's banishment from the heavenly plain-provides the narrative bridge joining the Izumo section to the central Yamato narrative of the court chronicles. Additionally, the theme of exile enables the narratives at once to relate Susano-o with Amaterasu by blood, while also establishing him as the ancestor of the chief Izumo deity Ōkuninushi (Ōnamuchi). Still further, we can say that banishment provides the narrative element relating Izumo deities (such as Ōkuninushi/Ōnamuchi) to those of the Yamato center even while subordinating them through their descent from the exiled god Susano-o. Narrative connection, genealogical relation, and political subordination of Izumo to Yamato-all are accomplished with the exile of Susano-o.

Such readings gain further resonance when we recall that the mythic conflict between Amaterasu and Susano-o was precipitated by tension surrounding the transfer of power from Izanagi to Amaterasu and that Susano-o's transgressions-destroying Amaterasu's rice fields, desecrating the hall where Amaterasu was to taste the first rice, and interrupting the weaving of heavenly garments-largely symbolize efforts to thwart Amaterasu's performance of the Niiname-sai, the harvest ritual of the Yamato court whose celebration by Amaterasu would certify her legitimacy as the new sovereign. ${ }^{75}$ Through the trope of exile, we can sum up, the court texts vividly imagine and dramatically assert an entire constellation of power, juxtaposing Amaterasu and Susano-o, Yamato and Izumo, center and margin, royalty and loyalty.

\footnotetext{
${ }^{73}$ Mizuno, Kodai no Izumo to Yamato, 19.

${ }^{74}$ Kōnoshi, "Constructing Imperial Mythology," 67. A full historical accounting of Susano-o worship would likely need to take into consideration influences from the Korean peninsula on the development of the cult.

${ }^{75}$ See the discussion in Ebersole, Ritual Poetry, 103, as well as the study by Robert Ellwood, The Feast of Kingship: Accession Ceremonies in Ancient Japan (Tokyo: Sophia University Press, 1973).
} 
Issues of genealogy, sovereignty, and legitimacy continue to reverberate as the Izumo section of the court chronicles draws to a close. Just as the Yamato narratives descend into Izumo beginning with Susano-o's exile, so too the texts pick up the Yamato thread once again as Susano-o's "descendent," the Izumo deity Ōkuninushi/Ōnamuchi, is called upon to surrender the land to deities sent down from the heavenly plain. More specifically, Amaterasu and the deity Takamimusubi send deities down to pacify and subdue the land, which is filled with unruly and troublesome divinities. Their subjugation ultimately requires the submission of Ōkuninushi- "the great lord of the land"- and the land-yielding myth involving Ōkuninushi thus sets the stage for the divine descent of the sun lineage, clearing the way for Amaterasu's grandson Ninigi to descend and govern the realm.

Interestingly, the initial attempts to subdue the unruly divinities end in failure, as the first deities sent down from Takamahara (Ame no hohi no mikoto and Ame no wakahiko, according to the Kojiki) end up allying with Ōkuninushi instead. ${ }^{76}$ Only after the deity Takemikazuchino-o descends and is about to kill Ōkuninushi's son does the great Izumo deity agree to surrender the land to Amaterasu's envoys. The agreement is conditional: in exchange for his submission to the envoys, Ōkuninushi requests and receives recognition for his own status as the deity of the great shrine of Izumo. "Then [Okuninushi] replied, saying: 'I will yield this Central Land of the Reed Plains in accordance with your commands. Only, if you will worship me, making my dwelling-place like the plentiful heavenly dwelling where rules the heavenly sun-lineage [amatsu hitsugi] of the offspring of the heavenly deities, firmly rooting the posts of the palace in the bedrock below... . Thus saying, he built a heavenly shrine (ame no miaraka) at the beach of Tagishi in the land of Izumo." "77 Several elements are noteworthy from the land-yielding sequence. At one level, the account operates in the manner of an engi-an origin myth for the founding of the great Izumo shrine, the seat of worship for Ōkuninushi. ${ }^{78}$ Simultaneously, the myth serves to authenticate claims made by the "sun lineage" for their own sovereignty over the Central Reed Plain and to deny the same for other deities and their possible descendants. Equally striking, however, the episode recapitulates in myth the historical process of incorporation mentioned earlier, illustrating in this case how a regional deity could be integrated into the Yamato hierarchy of status, receiving privileges and prestige in return for submission and loyalty to the Yamato center. As the

\footnotetext{
${ }^{76}$ According to the Nihon shoki main text, three deities were sent down initially but failed to perform their mission: Ame no hohi, Take mikuma no ushi, and Ame wakahiko; Aston, Nihongi, 64-65.

${ }^{77}$ Philippi, Kojiki, 134-35, modified. See Kurano and Takeda, Kojiki/Norito, 123.

${ }^{78}$ From at least the Heian period, the shrine has additionally been considered a seat of worship for Susano-o as well. See Matsumoto, "Susano-o shinkō no rekishi," 57.
} 
Izumo section draws to a close in the royal myths, Ōkuninushi withdraws to govern "things unseen" (kakuretaru koto), ${ }^{79}$ and the main Yamato narrative continues with the descent of Ninigi, bearing among other things the divine sword first discovered in Izumo by Susano-o. Looking back at the Izumo section of the court chronicles-from Susano-o's banishment to Ōkuninushi's surrender - the role of exile in helping simultaneously to connect and subordinate Izumo to Yamato can be charted genealogically as shown in figure 1 .

\section{THE DEVELOPMENT OF AN IZUMO PERIPHERY}

Given the themes of conquest and resistance animating the narrative of Ōkuninushi's surrender, scholars have long attempted to fathom the degree to which the antagonism expressed in the myth reflects some aspect of historical reality and why Izumo in particular appears on the receiving end of Yamato subjugation in the court chronicles. It was once popularly suggested that Izumo may have been the base of a distinct ruling group that held sway widely over the land, whose eventual conquest came at the hands of the expanding Yamato kingdom. ${ }^{80}$ Certainly, all evidence indicates that Izumo constituted a unique and powerful cultural center by the end of the Yayoi 弥生 period (ca. $400 \mathrm{BCE}-$ ca. $250 \mathrm{CE}$ ), as is clear from the unique style of burial mounds found in the region, the great size of these distinct mounds, and the vast numbers of bronze artifacts recovered from local burial sites. ${ }^{81}$ Despite evidence of trade networks and cultural exchange between Izumo and other areas of Japan, however, neither widespread Izumo hegemony nor Yamato military conquest is attested. ${ }^{82}$ As a result, scholarship has largely shifted toward exploring the symbolic function played by Izumo in the royal myth-histories. In this light, it has been suggested that the unique role of Izumo in the court chronicles may evidence Izumo's status as one of the last autonomous regions to be assimilated within the expanding Yamato polity and that Izumo may thus function in the court texts as paradigmatic of the broader process of Yamato expansion as a whole. ${ }^{83}$ Similarly, the resistance and subjugation of Izumo may have been exaggerated within the court chronicles exactly in order to amplify the actual degree of Yamato hegemony over territory for which it had in fact only tenuous control. Such an exaggerating function may be

\footnotetext{
79 Sakamoto Tarō et al., eds., Nihon shoki, vol. 67 of Nihon Koten Bungaku Taikei (Tokyo: Iwanami, 1967), 150-51.

${ }^{80}$ See the discussion of theories regarding early Izumo in Matsumae, Nihon no kamigami, 49.

81 Anders Carlqvist, "The Land-Pulling Myth and Some Aspects of Historic Reality," Japanese Journal of Religious Studies 37, no. 2 (2010): 196-201; Shiraishi Taichirō, "Wakoku tanjō," in Wakoku tanjō, vol. 1 of Nihon no jidaishi (Tokyo: Yoshikawa Kōbunkan, 2002), 43-44.

${ }^{82}$ See Carlqvist, "Land-Pulling Myth," 196-204; Shiraishi, "Wakoku tanjō," 45; Mizuno, Kodai no Izumo to Yamato, 20; and Matsumae, Nihon no kamigami, 49.

${ }^{83}$ Mizuno, Kodai no Izumo to Yamato, 24.
} 


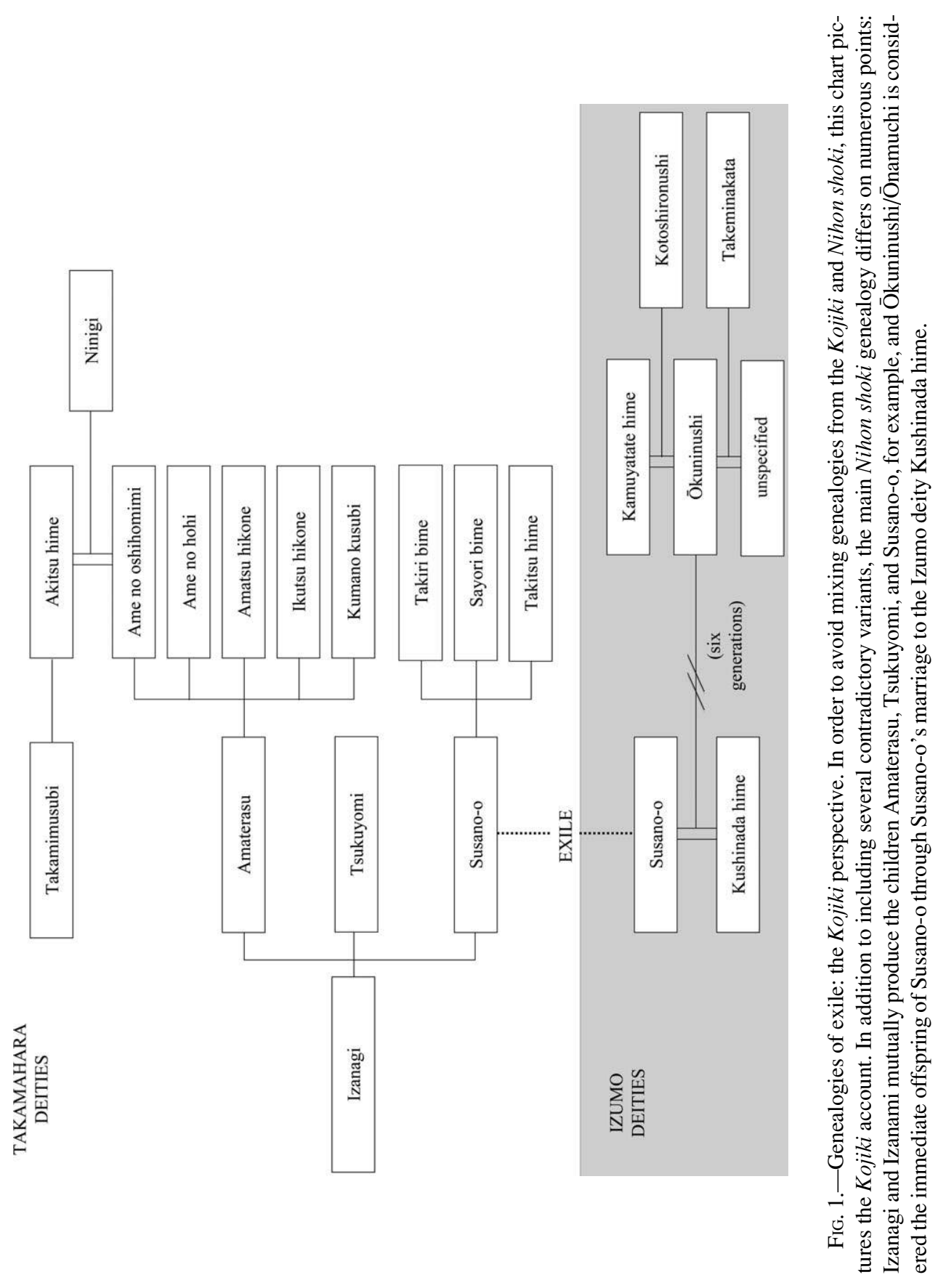


reflected, for example, in the way that an Izumo deity-Ōnamuchi-comes to function in the court texts as the leading representative of all earthly deities: Ōkuninushi. As such examples suggest, while the exact historical background for the myths remains undefined, the singular place held by Izumo in the narrative imagination of the Yamato myth-histories is unmistakable.

Paralleling in many ways the mythic assimilation of Izumo deities into a Yamato framework, the archeological record also clearly reflects the gradual absorption of Izumo elites into the Yamato cultural orbit beginning in the Kofun 古墳 period (ca. 250-592). Distinctive keyhole shaped tombs, for example-which emerged first in the Yamato region, foreshadowing the rise of a nascent Yamato polity - began appearing in Izumo by the end of the third century. ${ }^{84}$ Prestige goods originating in Yamato have been excavated from such tombs in Izumo dating at least to the sixth century, including ceremonial swords inscribed with honorific titles bestowed upon regional elites by the Yamato center. ${ }^{85}$ Flowing in the opposite direction, centripetal tribute from the great Izumo shrine is recorded in Yamato from around the same period, ${ }^{86}$ suggesting that by the late Kofun era, relations of tribute-in exchange for titles and articles of prestige-were being woven and etched into the larger cultural and political landscape.

\section{IZUMO MYTH AND YAMATO COURT RITUAL}

As we move into the period for which the written records of the Yamato court become historically more reliable, the absorption of Izumo elites into a Yamato-based hierarchy becomes visible in a new dimension: the ritual life of the court. Just as Izumo held a singular position within Yamato myth, the hereditary elite of Izumo also came to hold a privileged position in the ritual life of the Yamato court, in distinct contrast to the role of other such regional nobility. This can be seen clearly in the prescribed visits to the court of the Izumo no kuni no miyatsuko - the hereditarily appointed regional leader of Izumo- to offer ritual tribute and praise before the figure of the sovereign. ${ }^{87}$ While the ritual was merely one strand within a much larger tapestry of state ceremony that helped construct and display the sacrality, power, and legitimacy of the royal line, it was also unique in that it is the only known occasion

\footnotetext{
${ }^{84}$ Watanabe Sadayuki, "Chi-iki ōken no jidai," in Shimane-ken no rekishi, ed. Matsuo Hisashi (Tokyo: Yamakawa Shuppansha, 2005), 57; see also Shiraishi, "Wakoku tanjō,” 48, 90-94; Carlqvist, "Land-Pulling Myth,” 201; and Piggott, Emergence of Japanese Kingship, 32-33.

${ }_{85}$ Piggott, "Sacral Kingship," 60; and Carlqvist, "Land-Pulling Myth,” 203.

${ }^{86}$ Piggott, "Sacral Kingship," 60.

${ }^{87}$ The position of Izumo no kuni no miyatsuko was appointed by the state and filled by the head of the leading family among the Izumo elite, the Izumo no Omi. While the office of kuni no miyatsuko was officially discontinued throughout the land following the Taika reform of 645 and the Yamato state's attempt to exercise greater centralized control over the provinces, the Izumo no miyatsuko continued to hold office through the Nara period and beyond.
} 
in which a regional kuni no miyatsuko came to the court to offer such ritualized praise. $^{88}$

Known by its liturgical name Izumo no Miyatsuko no Kamuyogoto (divine laudatory words of the Izumo chieftain), the praise ritual was in fact an elaborate, multiyear affair, set into motion each time the office of Izumo miyatsuko was passed down from one generational leader to the next within the Izumo no Omi family. The process thus began when the incumbent Izumo leader (who was also the chief priest at the great Izumo shrine) first journeyed to the capital to receive his appointment, along with congratulatory gifts from the state. After returning to Izumo and undergoing a yearlong period of purification, the ritual culminated when the new miyatsuko journeyed back to the Yamato capital to perform the praise ritual itself. ${ }^{89}$ There, before the Yamato sovereign in the courtyard of the Daigokuden - the Great Hall of State within the royal palace- the miyatsuko blessed the ruler with words of praise and tribute, including the following: ${ }^{90}$

Thus do I, inheriting this tradition,

Perform the worship service,

And as the morning sun rises in glittering beauty

Do present, as tokens of homage of the deities and as tokens of homage of the Omi,

The sacred treasures of divine blessing. Thus I humbly speak ...

May you rule as an incarnate deity [akitsu mikami] the Great Eight-Island Land.

This performance was accompanied by offerings of tribute from Izumo to the sovereign - including jewels, a sword, and a mirror, as well as cloth, a horse, swans, and food offerings - while the Izumo miyatsuko and his followers were further bestowed with gifts and advances in rank. ${ }^{91}$

As with the Yamato myths involving both Susano-o and Ōkuninushi, the kamuyogoto liturgy was also infused with themes of genealogy, sovereignty,

${ }^{88}$ Matsumae, "Izumo no Shinwa," 110-11.

${ }^{89}$ The ritual grew still more elaborate over time: in its complete form, the year-long period of purification followed by recitation at court was repeated again upon completing the first praise ritual-a process aptly illustrating Mary Douglas's dictum that "ideas concerning pollution and purification are used to mark the gravity of the event and the power of ritual." See Aoki Kazuo et al., eds., Shoku Nihongi II, vol. 13 of Shin Nihon Koten Bungaku Taikei (Tokyo: Iwanami Shoten, 1990), 456-57; and the entry for "Izumo Shinko" in Shinto Jiten, ed. Kokugakuin Daigaku Kenkyujo (Tokyo: Kobundo, 1999), 318; as well as Maeda Haruto, Kodai Izumo (Tokyo: Yoshikawa Kōbunkan, 2006), 108; and Mary Douglas, Purity and Danger: An Analysis of the Concepts of Pollution and Taboo (New York: Routledge, 1991), 96.

${ }^{90}$ Donald Philippi, Norito (Princeton, NJ: Princeton University Press, 1990), 72-75, modified; see also Kurano and Takeda, Kojiki Norito, 452-57.

${ }^{91}$ See Felicia Bock, trans., Engi-shiki: Procedures of the Engi Era, bks. 1-5 (Tokyo, Sophia University, 1972), 114-15. 
legitimacy, submission, loyalty, tribute, and prestige. Indeed, the ritual acted on one level to assert a connection between the present moment of the participants and the time and space of the royal myth-histories, as can be seen in the motifs which structure the three sections of the liturgy. The first section begins by establishing the credentials of the kuni no miyatsuko himself as the chief priest of the great Izumo shrine, responsible for the worship of both "the blessed offspring of Izanagi" and "the land-creator" Ōnamuchi (Ōkuninushi). ${ }^{92}$ In the second section, the liturgy shifts to the time of myth, recalling how the "distant ancestor" of the Izumo leader - the deity Ame no hohi no mikoto - was sent down from the heavenly plain to pacify and subdue the land, which Ame no hohi managed to do by causing Ōnamuchi to relinquish control. ${ }^{93}$ The final section then serves to synthesize the first two, narrating the origin of the ritual itself by explaining how the heavenly deities charged Ame no hohi with "blessing the great reign of the sovereign as eternal," a task inherited genealogically by the Izumo miyatsuko in the mythically charged present. As the Izumo leader confirmed during the ritual, "thus do I... inheriting the tradition, perform the worship service ... and fearfully and reverently, do speak the congratulatory words of divine blessing. ${ }^{94}$

Echoing the submission of both Susano-o and Ōkuninushi within the Yamato myth-histories, the Izumo chieftain's recitation effectively reiterates the rejection of Izumo autonomy before the "sun lineage" of Amaterasu, offering instead a conspicuous display of loyalty and tribute. For heuristic purposes, we can visually chart homologies between the myth of Susano-o's banishment to Izumo, Ōkuninushi's land-yielding, and the kamuyogoto praise ritual as follows, drawing attention to the ways both myth and ritual inscribe Izumo within a Yamato-based hierarchy, assimilating and subjecting Izumo elites across distinct moments in mythic and historical time, while confirming the rightful rule of the sun line, and by extension the Yamato state (see table 1).

At the same time, such a chart highlights certain elements while obscuring others. Most fundamentally, it presents a vision of power and sacrality centered in Yamato, and we should not forget that texts from Izumo offer a very different perspective. As discussed earlier, none of the passages from the Izumo Fudoki connect Susano-o with the royal line, nor do they even mention Amaterasu. Neither does the Fudoki ever depict Ōnamuchi (Ōkuninushi)

\footnotetext{
92 The praise liturgy names the "blessed offspring of Izanagi" as Kushimikeno no mikoto 櫛御気野命, the great deity of the Kumano shrine in Izumo, a principle shrine worshipped by the Izumo Omi family. Kushimikeno is frequently presented in scholarship as an alternate name for Susano-o (see Kurano and Takeda, Kojiki/Norito, 452-53), although this connection isn't clearly made in either the Izumo kamuyogoto or the Izumo Fudoki. On this point, see Matsumoto, "Susano-o shinkō no rekishi," 53.

${ }^{93}$ As I discuss below, this represents a deviation from the official narrative of the Yamato court chronicles.

${ }^{94}$ Philippi, Norito, 72-73; see also Kurano and Takeda, Kojiki/Norito, 454-57.
} 
TABLE 1

Parallel Relationships: Susano-o, ŌKuninushi, and the Izumo Miyatsuko

\begin{tabular}{llcc}
\hline \hline & \multicolumn{3}{c}{ Zone of Interaction } \\
\cline { 2 - 4 } & $\begin{array}{c}\text { High Heavenly } \\
\text { Plain/Izumo }\end{array}$ & $\begin{array}{c}\text { Central Reed } \\
\text { Plain/Izumo }\end{array}$ & $\begin{array}{c}\text { Yamato } \\
\text { Capital/Izumo }\end{array}$ \\
\hline $\begin{array}{l}\text { Yamato representative } \\
\begin{array}{c}\text { Offering, surrender, } \\
\text { or tribute from Izumo }\end{array}\end{array}$ & Amaterasu & $\begin{array}{c}\text { Envoys of Amaterasu } \\
\text { and Takamimusubi } \\
\text { Okuninushi }\end{array}$ & Yamato sovereign \\
\hline
\end{tabular}

yielding sovereignty over Izumo. Even the text of the kamuyogoto, performed at the Yamato court, constitutes a deviation from the Yamato-centered myths: whereas the royal myth-histories portray Ame no hohi as a failed envoy of the sun deity who ended up allying with Ōkuninushi, the kamuyogoto portrays the deity instead as the honored ancestor of the Izumo Omi and the chief deity credited with pacifying Ōnamuchi/Ōkuninushi in Izumo.

Regarding such discrepancies, it's been suggested that the kamuyogoto liturgy stakes out a position midway between the Izumo- and Yamato-based texts, mediating between the divergent mythic worldviews of the two regions. ${ }^{95}$ In this sense, the ritual performance has been seen as negotiating a kind of settlement, offering a conspicuous display of loyalty and tribute from Izumo in return for greater recognition of genealogical status within the Yamato hierarchy. ${ }^{96}$ Matsumae Takeshi summarizes the context for such performances as follows:

For all leading families at this time, the most important concern for establishing one's social standing was to get one's family's myths adopted by the court, and to get one's clan genealogies woven into the royal genealogies. There were several ways to bring one's family traditions into the court: by providing one's daughter as a consort to the sovereign, thereby bringing one's natal traditions into the royal family's, or by taking part in the various roles involved in the ceremonies of royal authority - the Daijosai, Chinkonsai, and enthronement ceremonies-by offering performances of one's ancestral rituals and narrating the origin of such rituals as a kind of allegiance myth. ${ }^{97}$

95 Matsumae, "Izumo no Shinwa," 95.

96 See ibid., 112; and Carlqvist, "Land-Pulling Myth,” 212-15.

97 Matsumae, "Izumo no Shinwa," 111-12. See also Isomae, Japanese Mythology, 41-42. 
Indeed, the kamuyogoto liturgy offers evidence that Izumo leaders had established one such niche, through which the divine offspring of Ōnamuchi were presented as protector deities for the Yamato sovereign. ${ }^{98}$ All of this may help to explain the conspicuous role of the Izumo miyatsuko in the ritual life of the early Yamato court, yet it is also possible to overstate the degree of Izumo prestige or autonomy achieved by the ritual performance of praise. In the end, while the ritual may have provided an opportunity for Izumo elites to press their claims for greater recognition within the Yamato hierarchy, at the same time this opportunity was always framed within a dramatic display of allegiance to Yamato authority, in a liturgy that amounted ultimately, in one scholar's phrase, to "words of submission" ( fukujū no kotoba $) .99$

Interestingly, the earliest known performance of the kamuyogoto ritual is recorded in a Shoku Nihongi entry from 716, which states that the Izumo miyatsuko named Hatayasu conducted the liturgy. ${ }^{100}$ The next performance was recorded in 724 by an Izumo miyatsuko named Hiroshima, who was himself one of the original editors of the Izumo Fudoki. Regarding the 716 performance, scholars are unsure whether the Shoku Nihongi entry marks the first occurrence of the ritual ever or simply the first recorded occurrence. ${ }^{101}$ It is striking, however, that this first known occurrence takes place a mere four years after the completion of the Kojiki, suggesting that both the Kojiki and the Izumo kamuyogoto ritual were aspects of a larger project on the part of the early Yamato court to authenticate its rule. It is also striking that no performance of the Izumo kamuyogoto ritual appears in the official histories after $833,{ }^{102}$ thus neatly bookending both the rise and the attenuation of the period in which the ritsuryo state most conspicuously attempted to assert its rule over the archipelago.

Before concluding, we should take a moment to reflect on the kamuyogoto ritual in light of the mythic episode with which we began concerning the banishment of Susano-o. In the charged actions performed by the Izumo miyatsuko, the order of things initiated during the age of the gods with Susano-o's banishment was revisited and affirmed. In the royal myths, Susano-o's expulsion from the heavenly plain provided the narrative means for tracing the ori-

\footnotetext{
${ }^{98}$ According to the kamuyogoto liturgy, Ōnamuchi presented three of his divine offspring to serve as “close protector deities" (近守神) for the sovereign. See Philippi, Norito, 74; and Kurano and Takeda, Kojiki Norito, 454-55.

${ }_{99}$ See the discussion of the kamuyogoto in Mitsusada, Nihon no rekishi, 84 .

100 Aoki et al., Shoku Nihongi, 2, 9, entry for 716/2/10 (the tenth day in the second month of year 716). The Yamato sovereign was not present for the first recorded performance of the liturgy in 716, but was represented on that occasion by an official from the Jingikan; see also Matsumae, "Izumo no Shinwa," 111.

101 Aoki et al., Shoku Nihongi, 457; see also Maeda, Kodai Izumo, 118-19.

102 Obinata Katsumi, "Kodai kokka no tenkai to Izumo, Iwami, Oki sangoku," in Shimane-ken no Rekishi, ed. Matsuo Hisashi et al. (Tokyo: Yamakawa Shuppensha, 2005), 103.
} 
gins of the principle deities of Izumo, at once relating them to the Yamato pantheon while also inscribing their subjection to that center. With the ritual recitation of praise by the sacred representative from Izumo, such asymmetric relations between the two regions were then periodically recalled and put on display.

During these reenactments, the kamuyogoto ritual included an offering of jeweled beads from the Izumo miyatsuko to the Yamato sovereign: white, red, and blue jewels "arranged in orderly strings of noble beads," presented with the words "may you rule as an incarnate deity the Great Eight-Island Land."103 Such an offering echoes distantly the bestowal of the string of jewels from Izanagi to Amaterasu mentioned in the royal myths describing the original transfer of sovereignty from Izanagi. It is possible, as has been suggested regarding Izanagi's gesture in the myth-histories, that the act of bestowing jewels plays on homonyms contained within the word tama (jewel 玉; soul 魂) to signify the transfer of divine charisma from one ruler to the other, and hence the legitimation of succession. ${ }^{104}$ Yet even if the gesture by the Izumo miyatsuko represented nothing more than the offering of sacred treasure, in such an act as well we glimpse one further convergence between mythic narrative and ritual practice in service of the consecration of power. ${ }^{105}$

\section{CONCLUSION}

We can begin to wrap up by rephrasing a question originally posed by Paul Veyne in a different setting: Did the Japanese believe in their myths? ${ }^{106}$ These myths? And what about ritual? Before discussing the privileging of "belief" inherent in such questions, we need first to clarify what we might possibly mean by "the Japanese." To reiterate, the audience for the earliest court texts was never any sort of "folk," much less a national community in the sense imagined by the early modern nativist scholars but rather the nobility who themselves comprised court society, a hierarchy of central and regional elites. Seen in this light, Orikuchi's thesis - that the mythic narrative of Susano-o's mourning and exile expressed the yearning felt by all Japanese people for a spiritual homeland - is a reading only made possible from the early modern

\footnotetext{
103 Philippi, Norito, 75; Kurano and Takeda, Kojiki Norito, 454-57.

${ }^{104}$ See the discussion in Ebersole, Ritual Poetry, 89-91.

105 Here I mean to draw attention to mythic parallels between Susano-o's gift to Amaterasu (of the divine sword from Izumo) and the Izumo miyatsuko's ritual offerings to the Yamato sovereign (of jeweled beads, a sword, etc.). It is striking, however, that there are two instances recorded in the Nihon shoki regarding rulers who are keen to examine the sacred treasures of Izumo, with sometimes lethal consequences for those involved. See the Nihon shoki entries for Süjin 60.7.14 and Suinin 26.8.3.

${ }^{106}$ See Paul Veyne, Did the Greeks Believe in Their Myths?, trans. Paula Wissing (Chicago: University of Chicago Press, 1988).
} 
period, following a complete restructuring of the relationship between text, sovereign, and nation. In contrast, the earliest texts must be viewed as part of a historiographic project on the part of the Yamato state, a project which sought to authenticate and consecrate a particular order of power through the medium of mytho-historic narrative.

We need also to consider the question of "belief" more closely. Every study of the earliest texts from Japan is faced with the challenge of balancing the rich trove of symbolic material contained within the myth-histories, on the one hand, with the clearly expressed political intent of the myths' compilers, on the other. For every study that recovers the rich symbolic logic within the court texts - unveiling the role of double burial, for example, or of silkworm cults within the royal chronicles - there is always the lingering question of how to regard the role of artifice on the part of the myths' "editors." 107 As an early scholar of Japanese literature expressed this tension, "Many myths have been suppressed or forcibly altered in order to make them conform to this pattern [of royal domination]. It would be a grave mistake to consider those parts of the Kojiki and Nihon shoki which deal with the 'Age of the Gods' (kamiyo, jindai 神代) as descriptions of the mythology of the Japanese people and it is a very delicate task to define the relative value of the myths collected in these works." 108 In the delicate task of determining their "relative value," however, perhaps the study of early Japanese myth does not require us to line up on either side of a divide between belief and unbelief. Indeed, perhaps the question of belief itself somehow misses the target. ${ }^{109}$ Rather, as James Scott has shown in other contexts, what we witness in myths and rituals such as those produced by the Yamato court may be understood best as the construction of a public transcript, "the self-portrait of dominant elites as they would have themselves seen." ${ }^{, 10}$ In this sense, Yamato myth and ritual should be viewed as a kind of sacred dramaturgy — a script enacted by members of court society to the degree that they were immersed and invested in the Yamato order of things.

\footnotetext{
107 The two works alluded to here regarding double burial and silkworm cults-Ebersole's Ritual Poetry and Como's Weaving and Binding, respectively-remain among the leading works in English for examining the interplay between symbolic structure and editorial agency within the earliest myth-histories.

${ }^{108}$ Frits Vos, A Study of the Ise Monogatari, vol. 2 (The Hague: Mouton, 1957), 2.

109 Though my discussion moves in a somewhat different direction, there exists a growing body of scholarship critiquing the notion of "belief" as an operative category for the study of contemporary Japanese religions. Among others, see Karen Smyers, The Fox and the Jewel (Honolulu: University of Hawai'i Press, 1999), 1-13; Thomas Kasulis, Shinto: The Way Home (Honolulu: University of Hawai'i Press, 2004), 27-37; and Ian Reader, Religion in Contemporary Japan (Honolulu: University of Hawai'i Press), 1-22.

110 James Scott, Domination and the Arts of Resistance: Hidden Transcripts (New Haven, CT: Yale University Press, 1990), 18.
} 
In considering the conjoining of the court's myth-histories with ritual practice, Scott's points remain suggestive: "The theatrical imperatives that normally prevail in situations of domination produce a public transcript in close conformity with how the dominant group would wish to have things appear and any analysis based exclusively on the public transcript is likely to conclude that subordinate groups endorse the terms of their subordination and are willing, even enthusiastic, partners in that subordination." ${ }^{11}$ If this is the case, such a public transcript should not then be treated as a record of interior belief but rather as a script reflecting the interests of the dominant, who were in a position to produce exactly such "command performances of consent" as we find in the praise ritual of the Izumo miyatsuko. ${ }^{112}$ This doesn't negate the possibility of belief in the myths and rituals that helped shape the royal theater of the Yamato state, but it rightly cautions us not to mistake symbolic enactments of power relations- "credible performances"-for outward expressions of interior belief.

If this all seems rather matter of fact, we are then ready to return to the questions we began with. If Orikuchi's exegesis of the Susano-o myth is inadmissible - resting as it does on projections of cultural homogeneity and shared national longing - where does this leave us regarding the widespread presence of exile as a theme throughout Japanese court society? In the departing wake of Orikuchi's kishu ryüritan theory, what should we make of the widespread trope of exile seen in the literature, law, oracles, and cultic activity of Nara and Heian Japan?

While rejecting Orikuchi's theoretical approach, I agree that with the banishment of Susano-o as a starting point, we can better understand the particular resonance of the trope of exile within court society. We can begin by noting that every narrative of exile imagines a certain constellation of power, divided between a privileged sphere and those who are relegated to the margins. From this follows two fundamental possibilities, out of which we may trace nearly endless variants. For those in positions of power, the banishment of others provides a persuasive narrative trope for asserting and maintaining their own centrality, as when it is woven into the ruling myths of the Yamato court, establishing relations of hierarchy between Amaterasu and Susano-o, and thereby a vision of power with the "sun lineage" of Amaterasu at its center. Yet as we find in other texts that emerged later within Japanese court society, the trope of exile could also be harnessed by those more marginal, in narratives which sought to question and reconsider the structures of inclusion and exclusion upon which Yamato court society rested. Through the politics

\footnotetext{
111 Ibid., 4.

112 Ibid., 20.
} 
and poetics of exile, we might say, all members of court society possessed a theme through which to comment upon the social order. ${ }^{113}$

In this regard, the ability to physically exile someone- to banish a person from the capital, for example, a primary social, ideological, and spatial center of court society - was without doubt a tool of those already inhabiting privileged spheres of power and one that made clear their control over access to the center. Yet the ability to imagine exile was not monopolized, and indeed in the cultures of Nara and especially Heian Japan, exile came to appear widely as a theme not only within myth, but in literature and legends, in poetry and diaries, and in the cultic imagination, expressed in oracles and revelations. Thus, while banishment was simply one sanction available to the state, it was also something more: exile provided a trope through which members of court society imagined not only the banishment of gods but also of heavenly beings from the moon, of legendary and literary characters, and of historical figures, some transformed into spirits. In this sense, narratives of exile in early Japan served not only to assert and inscribe various constellations of power, but also to reveal and reimagine the order of society and the circulation of power within it, whether sacred or otherwise.

\section{University of Puget Sound}

${ }^{113}$ If this sounds too egalitarian for the elite world of the Japanese court, we might recall that the oracles narrating the exiled Sugawara Michizane's posthumous return to the capital as a vengeful deity were revealed by a child, an ascetic, and a female shaman, leading to the establishment of a shrine to Michizane eventually patronized by the state. 